\title{
INSULIN RESISTANCE AND BIRTH WEIGHT
}

\author{
Dagmar Horáková, Gabriela Janoutová, Vladimír Janout
}

\begin{abstract}
Department of Preventive Medicine, Faculty of Medicine, Palacký University, Hněvotínská 3, 77515 Olomouc, Czech Republic
\end{abstract}

Received: April 25, 2005; Accepted: May 19, 2005

Key words: Birth weight/Insulin resistance/Diabetes type II

This review article describes the scientific evidence for the relationship between birth weight and insulin resistance. Most studies demonstrate that low birth weight is closely connected to insulin resistance and later development of diabetes type II in adulthood. For this reason it is important for clinicians to focus on the personal history of the patient's birth weight. In patients with low birth weight, primary measures should be taken to prevent the development or progress of insulin resistance, and late consequences like diabetes and atherosclerotic complications.

\section{INTRODUCTION}

Insulin resistance is an important phenomenon in relation to obesity, diabetes type II and the metabolic syndrome. The metabolic syndrome includes clinical, biochemical and humoral deviations linked to a primary defect which is insulin resistance. It is a disease with high prevalence, estimated to be $25-30 \%$ in the adult population and $50 \%$ in the elderly. For this reason, clearly defined basic mechanisms and pathogenesis of insulin resistance development, as well as main risk factors of further progress, are essential ${ }^{27}$.

The term insensitivity to insulin or insulin resistance, was first used in 1939, when Himsworth and Kerr characterised two types of diabetes 9 . However decisive evidence for insulin resistance participation in the development of diabetes type II, atherosclerosis or hypertension has come up with Stout's demonstration of a relationship between insulin and atherogenesis at the end of the 1960s and discovery of a test for insulin sensitivity using euglycemic hyperinsulin clamp. Reduced biological response is not only an indication of insulin action in metabolic processes, that is changes in glucose utilisation and protein and lipid metabolism, but also for other insulin actions like growth and differentiation in tissue defects, DNA synthesis and gene transcription regulation.

Impairment of insulin sensitivity is mainly determined by glucose concentration in the blood which is enhanced, subsequent hyperglycaemia is followed by excessive secretion of insulin by the beta cells of Pancreatic Islets, leading to hyperinsulinaemia. Tissue intake and utilisation of glucose defect is the most studied aspect of insulin resistance.

Insulin resistance is a condition, where insulin is not able to ensure adequate peripheral tissue glucose utilisation, especially in the muscles and liver ${ }^{3}$. It is connected with the impairment of transmission - transduction of the insulin signal to cells, that is with insulin receptors and postreceptor actions inside the cell. There is a glucose transport and phosphorylation failure mainly in muscle cells and reduction in glycogen stores in the muscles and liver. This is due to both primary genetic factors and secondary factors connected with the environmental influence. One genetic factor is rare protein mutations at different levels of the insulin transduction cascade, leading to extreme hyperinsulinaemia. The prevalence of syndromes like acanthosis nigricans, leprechaunismus or Rabson-Mendehall syndrome is rare in the Czech Republic and their epidemiological importance negligible. More often and more important is insulin resistance, where more genes play a role and postreceptor processes are affected. Due to genetic polymorphism there is a mass occurrence of insulin resistance. Many variants with demonstrated predisposition untill clinical manifestation exists, and importance of external factors like nutrition, lifestyle etc., influencing changes from predisposition to clinical stages, are increasing.

There is a range of transduction inhibitors of insulin signal - TNFalfa, leptin, Plasminogen activator inhibitor (PAI-1), transport proteins of lipids, resistin and others known today. Their effect is connected with inhibition of peroxisome proliferator-activated receptors (PPARgama) which activate specific fat tissue genes coding regulatory proteins in fat cells metabolism and ensuring control of triacylglycerol (TAG) production from fatty acids and glucose homeostasis. All these factors mutually influence and decrease insulin sensitivity by either direct effect on the insulin signal cascade or indirectly through mutual linkage and metabolic effects. Many of these factors are created in abdominal and visceral fat tissue and in case of obesity is increasingly washed out. This may explain the close relationship between obesity and insulin resistance. Obesity not only causes insulin resistance by increasing formation of the agents mentioned above, but also in the opposite, increased formation of those agents may be a reason for insulin resistance leading to changes 
in fat metabolism including obesity ${ }^{18}$. It indicates a close connection between weight of the individual and insulin resistance. Fetal malnutrition and subsequent low birth weight is an interesting phenomenon, connected with the problem of insulin resistance, diabetes type II and metabolic syndrome.

\section{LOW BIRTH WEIGHT \\ - A RISK FACTOR OF INSULIN RESISTANCE}

Growth of the human body is rightful process under physiological conditions. Growth patterns are the result of complex system of their control. The growth harmony consists in complicated regulation of the growth process. Each tissue is just necessary amount in a given time and its differentiation is accomplished in a particular time to be able to start function in the organism. Growth is a result of complex integration of genetic and environmental factors like adequate nutrition, which are necessary for physiological growth and development ${ }^{17}$. Malnutrition is a risk factor in every phase of the growth but mainly in prenatal and postnatal period. If there is a nutrition deprivation exposure of the foetus, regardless of the origin, development and persistence of adaptation mechanisms in a postnatal period is tax for malnutrition. Prenatal physiological growth rate and length is the same for human body within decades, contrary to postnatal growth rate, which is quicker. Reasons for this change are combination of genetic factors, better nutrition and elimination of important diseases of childhood, so that current generation may fully realise hereditary growth and development potential. In a recent decades there are changes in prenatal development in terms of perinatal mortality decrease and ability of neonatology to ensure foetus survival even with low weight and low gestational age. Individuals with low birth weight whose number is increasing in a population are suitable for research how their organism is adapted to unfavourable development conditions and subsequent occurrence of certain diseases.

The first relationship between the low birth weight and disease was described in coronary heart disease, and the Barker hypothesis was formulated saying, that the origin of some diseases in adulthood may be in foetal life. The hypothesis is based on the epidemiological observation of foetal malnutrition and morbidity in the adulthood. Low birth weight and coronary heart disease was discovered first and then similar and even closer connection was found in low birth weight and second-type diabetes and insulin resistance in the adulthood. In spite of Barker's hypothesis criticism, many epidemiological studies provide sufficient evidence for considering consequences for individuals with this potential risk factor ${ }^{4}$. Low birth weight and low gestational age may be considered as a potential risk factor for both subsequent disease and a reason for prevention of behavioural risk factors like smoking, wrong nutrition, physical inactivity and others. On the other hand every physician when taking care of patients, should also ask about the intrauterine development and information regarding birth of the patients.

\section{DISCUSSION}

There are several epidemiological studies dealing with the relationship between the low birth weight and probability of diabetes development.

In the study performed in Hertfordshire, Great Britain, 408 males in the age of 59-70 were investigated for glucose tolerance test. At the same time, birth weight was ascertained and linear inversion correlation between the glucose intolerance and birth weight was found. Prevalence of glucose intolerance was $14 \%$ in two highest categories of birth weight and $36 \%$ in two lowest ones. If body mass index (BMI) was taken into consideration, the relationship was even stronger and the odds ratio for prevalence in the highest category in comparison with the lowest category of birth weight was 6.6 (ref. ${ }^{22}$ ).

In Uppsala, Sweden, glucose tolerance test was performed in males of age 50, born in 1920-1924. In their sixtieth, after 10 years, test was repeated and results compared with their birth weight ascertained in the years 1970-1973. Gradual increase of diabetes prevalence in the age 60 was found, dependent on the decreasing birth weight. This relationship was statistically significant when BMI was used as a complementary variable only. There were a strong relationship found between diabetes and low ponderal index. In the lowest ponderal index quintile three times more prevalence of diabetes was found then in other quintiles.

In Preston, Great Britain, glucose tolerance test was performed in 266 males and females in the age of 50 and results compared with birth weight. Linear inverse correlation was found and similar relationship was found for ponderal index ${ }^{22}$.

In the USA in the "Health professionals Follow-up Study", frequency of diabetes was compared with birth weight in the group of 22693 males with average age 61 . Odds ratio for diabetes was 1.9 in the lowest category of birth weight in comparison with the average birth weight $^{22}$.

In the USA in Pima Indians, birth weight was ascertained in 1179 individuals in the period of 1965-1972 and in their age of 20-39 was compared with prevalence of diabetes. Relationship of "U" shape was found, that means increased prevalence of diabetes in subjects with birth weight either lower than $2.5 \mathrm{~kg}$ or higher than $4.5 \mathrm{~kg}$ only. Odds ratio for diabetes was 3.8 in the lowest birth weight compared to normal birth weight ${ }^{15}$.

In the Institute of Preventive medicine in Oslo, Norway, a study dealing with the relationship of birth weight, gestational age and first-type diabetes was performed. Data were obtained from the Birth Registry and Children Diabetes Registry in Norway. All individuals born in 1974-1998, that is 1382602 subjects were followed-up in 1989-1998. The incidence of diabetes increases linearly 
with birth weight. The highest rate was found in birth weight 4-4.5 kg compare to birth weight $2.0 \mathrm{~kg}$ (95\% CI 2.5-3.9). No significant association between gestational age and diabetes was found ${ }^{22}$.

Range of other studies confirmed hypothesis, that people born "small" are in the higher risk of diabetes in their adulthood. All studies more or less found this relationship but none of them disprove it. In some studies, other dimensions of newborns were evaluated and it seems that not only birth weight but also other dimensions may be connected with diabetes. In Preston's study big head circumference and big placenta compared to the size of the foetus, were found as a risk factor for the future development of diabetes. Another result from this study identifies the birth weight association with insulin resistance. Individuals with low birth weight suffered with insulin resistance in adulthood and this was increasing with the increased BMI. So that to be "lean" in birth or in adulthood has just the opposite effect on insulin resistance. Individuals small in birth and obese in adulthood are the most resistant to insulin.

Mechanisms, which could explain relationship between foetal growth and insulin resistance and later diabetes, have not been clearly discovered. It may be due to specific gene for insulin resistance both in the foetus and in adult person as well. Insulin has central role in foetal growth ensuring the speed of the growth according to supply of nutrients. McCance's theory is saying that genes predisposing to insulin resistance and diabetes in adulthood enable survival of foetus in uterus under condition of malnutrition. This is the explanation for "small" children becoming insulin resistant when being adults - the hypothesis of "small children survival". But apart of genetic factors, there is an intrauterine environment, which may be responsible for birth weight. Penrose summarised that birth weight is influenced from $62 \%$ by intrauterine environment, from $20 \%$ by parent's genes and from $18 \%$ by foetus own genes ${ }^{21}$.

Animal experiments prove that insufficient nutrition may impair foetal growth and influence structure and physiology of different organs and tissues. Reduction of nutrients intake by ligating unilateral uterus artery in guinea pigs or low protein diet within pregnancy in rats are examples, when those stimuli, if acting in the critical point of the organism development, may have a lifelong effect.

Connection of low birth weight and insulin resistance or diabetes in adulthood may be a result of foetal malnutrition due to poor nutritional reserves of mother, not adequate flow of the blood in uterus or destruction of nutrients in the placenta. Malnutrition then directly acts on insulin sensitive tissues like liver, skeletal muscles or pancreas and function its beta cells.

Foetus and placenta are autonomous from endocrinological point of view. As an answer to malnutrition, foetus decreases insulin secretion and increases levels of some hormones in order to adjust foetus and placental metabolism for maximal utilisation of available nutrients, allocation of blood supply and alteration of growth speed.
Levels of adrenaline and cortisol in particular are increasing, both having hyperglycaemic effect and at the same time levels of other hormones and growth factors are decreasing. All hormones have exactly programmed functions and target effects in specific periods of development and their impairment may cause defect in physiological functions for the whole life ${ }^{12}$.

Hypothalamus-hypophisis axis activity may slow down foetal growth. Stimulation of its function in rats leads to very high levels of plasma cortisol, which slow down rat growth and rats become permanently intolerant to glucose. Analogically permanently programmed higher activity of hypothalamus-hypophisis axis may help to explain pathogenesis of insulin resistance and connect low birth weight with insulin resistance and diabetes type II. Slow foetal growth may also lead to small muscle mass and impairment of physiology of skeletal muscles as one of the most important sites of insulin action ${ }^{11}$.

Another question, which is disputable is whether in relationship between low birth weight and diabetes type II has decisive role rather insulin resistance or defect in insulin secretion. Another question is whether in those impairments genetic or environmental factors especially malnutrition prevail. Most authors support hypothesis of low birth weight or low ponderal index being associated with insulin resistance and subsequent risk of diabetes type II. But in all cases there is a common understanding, that whatever mechanism is between low birth weight and diabetes, obesity and its control is the most important preventive factor in such risky individuals.

\section{CONCLUSION}

Low birth weight is probably part of metabolic syndrome. It is associated with insulin resistance, secondtype diabetes type II and primary hypertension. Even the long distance between the birth and subsequent diseases in the older age, it appears that both birth weight and later increase of BMI are hereditary part of metabolic syndrome. In spite of the fact, that pathogenesis is not clearly explained, it is worthwhile to register data on birth weight of the individual and focus preventive measures on those with higher risk. This may help to influence positively the unfavorably increasing prevalence of metabolic syndrome.

\section{ACKNOWLEDGEMENTS}

This work was supported by the IGA No. 1A8250-2/2004 grant.

\section{REFERENCES}

1. Aitman TJ. (2003) Genetic medicine and obesity. N Engl J Med 348, 2138-2139.

2. Anděl M. Hyperinzulinismus, inzulínová rezistence. In: Houdek L, editor. Diabetes mellitus 2. typu. Galén, Praha, 1996, p. 99-103. 
3. Anděl M. A. Diabetes Mellitus 2. Patofyziologie. In: Houdek L, editor. Diabetes mellitus a další poruchy metabolismu. Praha: Galén, 2001. p. 18-25.

4. Barker DJP, Winter PD, Osmond C, Margetts BM, Simmonds SJ. 13: Weight in infancy and death from ischaemic heart disease. In: Barker DJP, Robinson RJ, editors. Fetal and infant origins of adult disease. London: British Medical Journal, 1992. p. 141-149.

5. Eriksson JG, Forsen T, Tuomilehto J, Osmond C, Barker DJ. (2003) Early adiposity rebound in childhood and risk of Type 2 diabetes in adult life. Diabetologia 46, 190-194.

6. De Fronzo RA, Ferrannini E. (1991) Insulin resistance. Diabetes Care 14, 173-194.

7. Ford ES, Giles WH, Dietz WH. (2002) Prevalence of the metabolic syndrome among US adults: findings from the third National Health and Nutrition Examination Survey. JAMA 287, 356-359.

8. Ghezzi F, Tibiletti MG, Raio L, Di Naro E, Lischetti B, Taborelli M, Franchi M. (2003) Idiopathic fetal intrauterine growth restriction: a possible inheritance pattern. Prenat Diagn 23, 259-264.

9. Himswort HP, Kerr RB. (1939). Insulin-sensitive and insulin-insensitive types of diabetes mellitus. Clin Sci 4, 119-152.

10. Hřebíček J, Janout V, Malinčíková J, Horáková D, Čížek L. (2002) Detection of insulin resistance by simple quantitative insulin sensitivity check index QUICKI for epidemiological assessment and prevention. J Clin Endocrinol Metab 87, 144-147.

11. Jaquet D, Leger J, Chevenne D, Czernichow P, Levy-Marchal C. (1999) Intrauterine growth retardation predisposes to insulin resistance but not to hyperandrogenism in young women. J Clin Endocrinol Metab 84, 3945-3949.

12. Jaquet D, Leger J, Czernichow P, Levy-Marchal C. (2002) The ef fect of in-utero undernutrition on the insulin resistance syndrome Curr Diab Rep 2, 77-82.

13. Jaquet D, Leger J, Levy-Marchal C, Czernichow P. (2003) Low birth weight: effect on insulin sensitivity and lipid metabolism. Horm Res 59, 1-6.

14. Kaplan NM. (1989) The deadly quartet. Upper-body obesity, glu- cose intolerance, hypertriglyceridemia and hypertension. Arch Intern Med 149, 1514-1520.

15. Knowler WC, Pettitt DJ, Saad MF, Bennett PH. (1990) Diabetes mellitus in the Pima Indians: incidence, risk factors and pathogenesis. Diabetes Metab Rev 6, 1-27.

16. Kuh D, Ben-Shlomo Y. (1997) A life course approach to chronic disease epidemiology: conceptual models, empirical challenges and interdisciplinary perspectives. Int J Epidemiol 31, 285-293.

17. Lebl J, Krásničanová H. (1996) Růst dětí a jeho poruchy. Galén, Praha.

18. Malinčíková J. (2002) Inzulínová rezistence u dětí prepubertálního věku. LF UP, Olomouc.

19. Mather KJ., Hunt AE., Steinberg HO, Paradisi G, Hook G, Katz A, Quon MJ, Baron AD. (2001) Repeatibility characteristics of simple indices of insulin resistance. J Clin Endocrinol Metab 86, 5457-5464.

20. Neel JV, Weder AB, Julius S. (1998) Type II diabetes, essential hypertension, and obesity as «syndromes of impaired genetic homeostasis»: the «thrifty genotype» hypothesis enters the 21 st century. Perspect Biol Med 42, 44-74.

21. Péče o nemocné cukrovkou 2003. ÚZIS 2004.

22. Phillips DIW. Birth Weight and the Future Development of Diabetes. International Workshop- Conference on Gestational Diabetes Mellitus. Diabetes Care 21 (Suppl 2), B150.

23. Reaven G. (1988) Role of insulin resistance in human disease. Diabetes 37, 1595-1607.

24. Reaven G. Insulin resistance, compensatory hyperinsulinemia and dyslipidemia in syndrome X. Atherosklerosis XI, Elsevier Science, Singapore, 1998.

25. Svačina S̆. (2003) Nízká porodní hmotnost a pozdější riziko diabetu 2. typu a metabolického syndromu. Vnitřní lékařství 49, 952-955.

26. Svačina Š. (2000) Obezita a diabetes. Maxdorf, Praha.

27. Svačina Š . (2001) Metabolický syndrom. Triton, Praha.

28. Svačina Š. (2003) Prevence diabetu. Galén, Praha. 